University for Business and Technology in Kosovo

UBT Knowledge Center

UBT International Conference

2017 UBT International Conference

Oct 29th, 5:00 PM - 5:15 PM

\title{
Justice reform and the Constituitional Court
}

Noela Ruço

Constitutional Court of Republica of Albania, noela@gjk.gov.al

Follow this and additional works at: https://knowledgecenter.ubt-uni.net/conference

Part of the Law Commons

\section{Recommended Citation}

Ruço, Noela, "Justice reform and the Constituitional Court" (2017). UBT International Conference. 217. https://knowledgecenter.ubt-uni.net/conference/2017/all-events/217

This Event is brought to you for free and open access by the Publication and Journals at UBT Knowledge Center. It has been accepted for inclusion in UBT International Conference by an authorized administrator of UBT Knowledge Center. For more information, please contact knowledge.center@ubt-uni.net. 


\title{
Justice reform and the Constitutional Court
}

\author{
Noela Ruço ${ }^{1}$ \\ ${ }^{1}$ Constitutional Court of Republica of Albania, Blv. Dëshmorët e Kombit, nr. 26 \\ Albania \\ noela@gjk.gov.al
}

\begin{abstract}
During these years Albania has experienced numerous political, economic and social developments, which naturally have been accompanied with certain developments in the legal framework. Not only were these initiatives about the adoption of different legal acts, but also about the practice of state institutions themselves in the materialization of the law in general and the constitutional law in particular. The activity of constitutional institutions, especially the constitutional control exercised by the Constitutional Court, during these years has highlighted some of the issues needed to be reviewed by the constitutional lawmaker in the framework of the justice reform. The constitutional amendments of 2016 also affected aspects of the organization, functioning and competencies of this Court which were reflected both in the constitutional provisions and the law on its organization and functioning. The most important amendment in the competencies of the Constitutional Court is related to the individual constitutional appeal, which gives the individual the right to oppose normative acts before the Constitutional Court.
\end{abstract}

Keywords: Justice, Constitutional Court, competence

\section{Introduction}

It's been 19 years since the date of entry into force of the Albanian Constitution. Numerous political, economic and social developments have occurred in the meantime, which are naturally accompanied with certain developments in the legal framework.

Not only are we referring to the initiatives for the adoption of different legal acts, but also to the practice of the state institutions themselves, mainly constitutional, in the materialization of the law in general and the constitutional law in particular.

The activity of constitutional institutions has been occasionally accompanied by broad or narrow interpretations of constitutional provisions, highlighting the need for their adaptation to the circumstances of the case. The Constitutional Court has interfered in these situations, providing the meaning of the constitutional norm. Despite its final interpretation, which leaves no room for discussion by the parties, practice has shown that the norm needs more than an interpretation; it should be adapted to the country's political reality. In this sense, the activity of constitutional institutions, especially the constitutional control exercised by the Constitutional Court, during these years has highlighted some of the issues that were needed to be reviewed by the constitutional lawmaker in the context of justice reform.

Since the entry into force in 1998, the Constitution has been revised three times with law no. 9675/2007; law no. 9904/2008 and law no. 88/2012. In the first case, in 2007, the extension of the 
term of office for elected bodies of local government became from 3 to 4 years. In the second case, in 2008, the most important changes were reflected in the election procedure of the President of the Republic, the government's confidence vote and the term of office of the General Prosecutor. In the third case, in 2012, an intervention was made to mitigate the immunity regime of some high public officials.

Subsequently, the systematic conflicts identified in the relations between the Assembly, the President and the General Prosecutor, the difficult procedures aiming to repeatedly block the appointing process of members of the Constitutional Court, etc., have pointed out problematic issues which seemed to originate from constitutional or legal norms, as well as from the extremely political approach of constitutional institutions.

The experience of these years has brought to attention the finding that the revision of the Constitution not always was oriented to the improvement of the justice system, despite the fact that indirectly the amended provisions (as the election of the President of the Republic or the limitation of the term of office of the General Prosecutor) have had a direct impact on the entire justice system.

\section{The constitutional amendments affecting the Constitutional Court}

The constitutional amendments of 2016 also affected aspects of the organization, functioning and competencies of the Constitutional Court which were reflected both in the constitutional provisions and the law on its organization and functioning.

Due to the role given by the 1998 Constitution and the law on the justice system, the President of the Republic, based on Article 125/1 of the Constitution, had the power to appoint the members of the Constitutional Court with the consent of the Assembly.

The President of the Republic has been set out in the Constitution with the capacity of the head of state, as recognized in the parliamentarian republics: i.e., a non-executive president. Article 90/1 of the Albanian constitution explicitly prohibits the governance of the President alongside the executive or lawmaker. For this reason, the discussion among the researchers of the constitutional law has been oriented towards seeing the functions of the President of the Republic in connection with preserving the legal certainty and implementing the law, controlling the appropriateness of the acts of the highest constitutional state authorities, representing the state and people as a whole and embodying the unity of the people and serving as a guarantee for the constitution.

In this context, the formula of electing the President, which was foreseen by the Constitution drafters of 1998, aimed at reaching a political consensus in the Assembly, to the effect of ensuring an extensive political support, being also translated into a support from the majority of electorate. This formula guaranteed the election of a consensual president, having the consent of a wide political spectrum, and not only the consent of the parliamentarian majority. The constitutional amendments of 2008 avoided the condition of reaching a consensus between the parliamentarian majority and minority, where in the fourth voting it is enough to achieve a simple majority (more than half of all members of Parliament) for electing the head of state. The election of the President of the Republic with half the votes of all members of the Assembly, bypassing the political consensus reflected a lack of broad political support, and also a lack of confidence from the parliamentary minority to the fundamental act of the state and the guarantees given by the figure of the head of state.

The constitutional mechanism of involvement of the President of the Republic and the Assembly was originally intended by the drafters of the Constitution in 1998, as the best solution compared to the previous provision. The 16 years experience (until the constitutional amendment in 2016) of the 
implementation of this constitutional procedure have proved a political nature approach of the consent of the Assembly for the high and constitutional judge, as well as for the General Prosecutor. The researchers but also policy makers have found that this selection formula is defective based on several factors such as:

- the role played by the President of the Republic for selecting the candidates;

- the political nature of the appointment procedure of the high judges in the Assembly;

- the minimum majority of not less than 36 votes to give consent by Parliament;

- unnecessary constitutional changes affecting the consensual formula of election of the President of the Republic, etc.

Thus, the previous constitutional mechanism for the election of judges of the Constitutional Court, although based on the mixed system by a simple majority, a minimum of 36 votes required to approve the candidacies seems to rule out a kind of consensus between the parties. Due to the circumstances created by the revision of the formula of election of the President of the Republic from consensual toward a clear political appointment, the guarantee given by the President's involvement in the election of these officials failed to establish credibility in the parliamentary majority.

The problems encountered in the procedure for the election of high and constitutional judges have brought on the agenda the constitutional revision for the required quorum needed for their selection. The process of selecting judges of the Constitutional Court not only was a matter of internal concern, since the European Union had consistently insisted on analyzing the problems related to the independence of the Constitutional Court, starting with the process of appointing of judges and proceeding with the guarantee of a hearing procedure and a regular and depoliticized vote. The appointment of judges should require "cooperation with the institution of the President in order to establish legal criteria to guarantee a qualitative composition of the Constitutional Court".

Based on Article 125 of the amended Constitution, the Constitutional Court consists of 9 members. Three members shall be appointed by the President of the Republic, three members by the Assembly and three members by the High Court. The members shall be selected among the three first ranked candidates by the Justice Appointments Council, in accordance with the law.

This formula implies the representation of several branches of power. Thus, for example, since the candidates of the judiciary will only be judges, the President and the Assembly must elect at least 2 members from other professions (lawyer, prosecutor, law professors or from the academic world, etc.). The Justice Appointments Council should carry a transparent process for the selection and ranking of the most qualified candidates appointed by The President, the Assembly and the Supreme Court. This council will rank the candidates according to the scientific criteria provided for in the organic law. The Assembly shall appoint constitutional judges by a majority of 3/5 of all members. This formula of election ensures the participation of some bodies and interest groups in the process, as each body has substantial and undivided competences with others, which will avoid blocking the process, thus creating the possibility of mixing the experiences of members of the Constitutional Court. Moreover, this process is not dominated by politics and it also enables balance of powers.

The purpose of these amendments is to provide the most objective criteria for the selection of candidates for members of the Constitutional Court. They are mainly defined in the Constitution, but are also envisioned in the law and are mostly focused on merit. The criteria required by the candidates are: professional experience not less than 15 years as a judge, prosecutor, advocate, law professor or lecturer in law, high-level jurist in the public administration. The candidates should also have participated in the academic field (not necessarily to have scientific titles, but this may be a preferential criterion) and also have a renowned activity in the field of human rights or related such as in the field of administrative law, constitutional law, European law etc. They should be assessed for professional skills, ethical and moral integrity; should have not assumed political functions in the 
public administration and should have not assumed leadership positions in political parties during the past 10 years from the date of application. The whole process of appointment should be characterized by transparency and publicity (criteria that have been missing up to now) as these elements contribute to the quality of constitutional justice and also to the perception and strengthening of public confidence in the independence of constitutional judges and consequently in the legitimacy of the guarantor of the Constitution.

The President of the Constitutional Court, no later than 3 months before the end of mandate of a Constitutional Court judge, as well as after the premature termination of the mandate, shall notify the appointing body regarding the vacancy. The procedure for the appointment of the new judge shall be completed no later than 60 days from the decision of the Constitutional Court that declared the end of the mandate. The appointing organs, within 30 daysfrom the opening of the application procedure, publish the list of candidates and send it to the Justice Appointments Council. The Council ranks the candidates based on their qualification. The list is associated with a report in writing, analyzing the meeting of legal conditions and criteria for each of the candidates.

In addition to moral integrity, an important step is the professional assessment focused on several parameters, such as professional experience in the legal field, the continuity of a decision given in other stages of the trial, the quantity and quality of the work performed, the respect of deadlines for announcement of the decision, active participation and assistance provided by the judge in the progress of the office / court in which he operates, availability, frequency of training courses, contribution to the solution of organizational problems, special merits in the field of teaching, etc. In the same line of reasoning, the important position of the Constitutional Court in the justice system implied the need to set high criteria in the selection of constitutional judges. The lack of clear rules about the process of appointing judges of the Constitutional Court has resulted in the blockage of the appointment process.

Only after the candidates for judges of the Constitutional Court will be selected through these fair procedures they will have the duty to persuade the society that their decisions are based on constitutional standards and values and are far from political considerations and private interests. Such judicial decision-making undoubtedly gains the respect of society but also increases the authority of the institution they represent.

\section{Competences of the Constitutional Court}

The most important amendment in the competencies of the Constitutional Court is related to the individual constitutional appeal, which gives the individual the right to oppose normative acts before the Constitutional Court as well as the power of the latter to examine within a more limited area of appeal individual. 65

The Constitution of 1998 provided that the Constitutional Court was competent to review individual constitutional complaints only for a due process of law as one of its most important powers. The extension of the jurisdiction of the Court toward a more effective protection of individual rights aimed at a greater protection of the individual against acts of public power. Paragraph 2 of Article

${ }^{65}$ A. Vorpsi, Procesi i rregullt ligjor në praktikën e Gjykatës Kushtetuese të Shqipërisë (2011), fq. 67. 
131 of the Constitution also provides for the review of the constitutionality of the law revising the Constitution, when the procedure for adopting this law has not been respected. 66

There is also a redefinition of subjects that can initiate a constitutional judgment. According to Article 134 recourse to address the Constitutional Court is sought upon the request of not only the entities previously envisaged but also from the subjects whose activity is the protection of human rights and fundamental freedoms as provided for in sub-paragraph "e" of Article 134 "any commissioner established by law for the protection of the fundamental rights and freedoms guaranteed by the Constitution".

These constitutional amendments establish the basis of an overall and comprehensive legal and institutional reform to improve the justice system in our country. The constitutional, legal and institutional solutions offered through this reform aim to realize the efficient functioning of the system, the self-regulatory capacity of the system, to strengthen the accountability of judges and the mutual control among the institutions, consolidate the career of judges and prosecutors through evaluation of merit, professional skills and honesty in the exercise of duty.

The implementation of these constitutional amendments has just begun and we believe that the reform of the justice system and the successful implementation of the constitutional and legal amendments will open a new stage in the functioning of the justice system in our country so that it can became realistically independent, impartial and equal to all citizens, significantly increasing their credibility in justice.

\section{References:}

1. A.Vorpsi, Procesi i rregullt ligjor në praktikën e Gjykatës Kushtetuese të Shqipërisë (2011)

2. A.Vorpsi, Jan Bergmann, Ankimi kushtetues individual. Përvoja gjermane dhe perspektiva shqiptare. Manual praktik. Maluka editor, Tiranë/Stuttgart, 2017.

3. ConstitutionoftheRepublicofAlbania, Amendinglaw76/2016, dated22/07/2016

4. Law No. 99/2016 on some additions and amendments of the Law No. 8577, dated 10.02.2000, "On the organization and functioning of the Constitutional Court of the Republic of Albania".

${ }^{66}$ The Constitutional Court shall, when recourse being sought for examining a law on the revision of the Constitution approved by the Assembly according to Article 177, control only the compliance with the procedural requirements foreseen in the Constitution. 